\title{
Psychological Wellbeing, Life Satisfaction And Environmental Satisfaction Of Government And Private Female Hostelites
}

\author{
Fatima Shaukat \\ Department of Applied Psychology \\ Lahore College for Women University \\ Amina Muazzam Butt \\ Department of Applied Psychology \\ Lahore College for Women University
}

\begin{abstract}
This study explores the interplay of environmental satisfaction, levels of psychological well being and life satisfaction in female college students of government and private hostels. A total of 86 female colleges students were selected from government hostel and private hostels. The Satisfaction with Life Scale by Diener (1984), the Affect Balance scale by Bradburn (1969) and the Hostel Environment Rating Scale by Shaukat \& Muazzam, (2010) were administered on the sample to measure life satisfaction, psychological wellbeing and satisfaction with the hostel environment, respectively. Results indicated that the private hostel group was higher in psychological wellbeing and had higher scores of satisfaction with the hostel environment. $(t(86)=4.41, p<.05$.) However, satisfaction with life scales showed insignificant results $(t(86)=6.74, p<0.01)$. Appropriate tests were applied to analyze the data. Besides discussing the results, the implication of the study was also discussed.
\end{abstract}

Key Words: Psychological Effects, Female Hostelites, Comparison Government Private Hostilites, Satisfaction

$$
\begin{aligned}
& \text { تلخيص }
\end{aligned}
$$

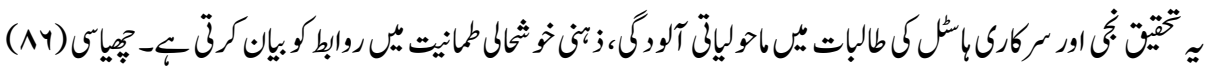

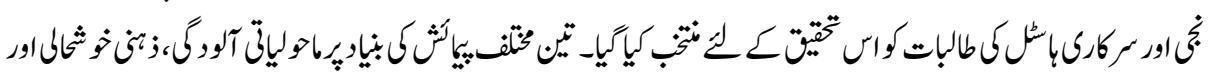

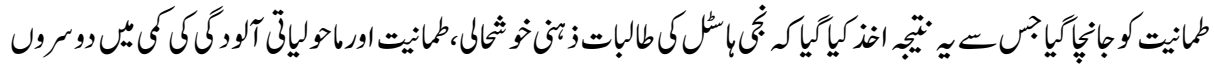

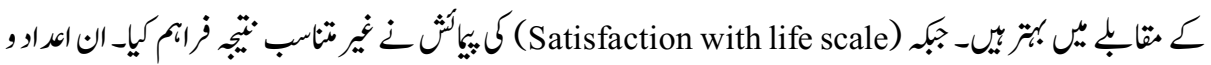

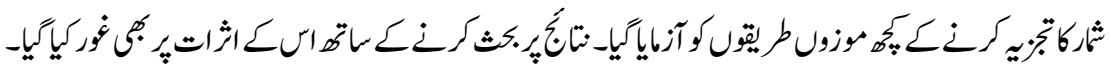

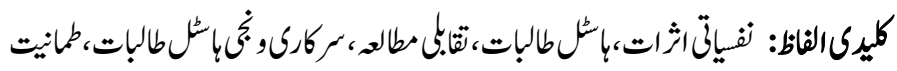




\section{Introduction}

Educational institutions and academic enrollment in Pakistan is increasing (Butt \& Rehman, 2010). The higher education sector has also been expanding. However, these institutions and colleges are more concentrated in larger, developed cities. There are few highly developed colleges in smaller cities and even fewer or none, in villages. Students from such places have to migrate to larger cities for higher education, therefore it can be reasonably assumed that that as higher education increases, the enrollment in hostels is also increasing. Since hostels play such a significant role in the students' lives, it is important to evaluate the impact of the hostel environment on the students' mental health (Botha, et al. 2013). According to Bell and Bromnick (1998), change and transition, including relocation of home, have been associated with mental and physical disorders in many studies (Fisher, Fraser \& Murray, 1986). If the individual fails to adapt and negative feelings within the new environment persist, it has been shown to be associated with high levels of loneliness, depression, increased physical health problems and allied difficulties (Fisher \& Hood, 1988).

One's surrounding environment can have a large affect on one's wellbeing (Muslim, Abdul-Karim \& Abdullah, 2012). Psychological wellbeing is a complex, multidimensional concept; according to Ryff (1989), who researched the concept in depth, it is comprised of six dimensions, such as: autonomy, environmental mastery, personal growth, positive relations with others, purpose in life and self-acceptance.

The present study makes use of the definition and the model given by Bradburn (1965):

"A person's position on the dimension of psychological well being is seen as a resultant of the individual's position on two independent dimensions - one of positive affect and the other of negative affect. The model specifies that an individual will be high in psychological wellbeing in the degree to which he has an excess of positive over negative affect and will be low in well being in the degree to which negative affect predominates over positive".

Certain terms are used in conjunction when exploring the concept of wellbeing. Subjective wellbeing, according to Diener (2006), refers to various evaluations (both positive and negative) such as cognitive evaluations, i.e. life satisfaction and work satisfaction etc., and affective reactions to life events, e.g. happiness and grief .

Positive affect refers to pleasant moods and emotions, such as joy and affection. Negative affect represent negative responses (moods and emotions) people experience in reaction to life events, such as anger, sadness, stress, loneliness, etc. Some negative affect is to be 
expected, even necessary at times; however extended periods of negative affect can hinder functioning, as well as make life unpleasant.

Psychological wellbeing is closely related to life satisfaction, often explored side by side in many researches. Though the terms are similar and overlapping, they do not mean the same thing. Life satisfaction is a report of how a respondent evaluates or appraises his or her life taken as a whole. The present study makes use of the definition given by Ed Diener:

"Life satisfaction is an overall assessment of feelings and attitudes about one's life at a particular point in time ranging from negative to positive. It is one of three major indicators of well-being: life satisfaction, positive affect, and negative affect" (Diener, 1984).

\section{Government and Private Hostels}

Government hostels are those that are funded by the government, often affiliated with or run by a government college. Private universities are not operated by governments though many receive public subsidies, especially in the form of tax breaks and public student loans and grants. Depending on their location, private universities may be subject to government regulation. Private hostels are those that are owned and run by privately, without government funding. The environment between these two types of hostels differs markedly, often due to lack of funding. Government hostels also often have more restrictions than private hostels.

\section{The Role of the Environment}

The environment plays a large role in the psychological wellbeing and life satisfaction of individuals. A large number of studies have attempted to gauge the impact of the environment on individuals' psychological wellbeing and life satisfaction, the environment being categorized into work environment (Shanfa, 2008), familial environment (Adams, King \& King,1996), or academic environment (Butt, 2010). Relatively few studies have focused upon the well being of students residing in school or college dorms. Indeed, research upon this area is a relatively new interest (Rogers \& Tennison, 2009; Bell \& Bromnick,1998; Wannebo \& Wichstrom, 2010).

\section{Terms in Literature}

Hostel is a word more commonly used in the eastern world. In western countries, equivalent words used to refer to hostel are dormitory (Rogers \& Tennison, 2009) residence halls (Bell \& Bromnick, 1998) or students' housing (Amole, 2008). In the present study, the term hostelite is used to refer to a student residing in a hostel; this term 
is commonly used in Pakistan. Adjustment to the dorms or hostels is also discussed under different terms such as residential satisfaction (Amole, 2008), psychosocial or emotional adjustment (Shaver, et al. 1986; Gerdes \& Mallinckrodt, 1994; Halamandaris \& Power, 1999; Lent, et al. 2009), place attachment, place identity (Chow \& Healey, 2008) and homesickness (Bell \& Bromnick, 1998).

\section{Adjustment Difficulties}

According to various authors, unable to adjust to the new environment can be due to a number of reasons. According to Bell and Bromnick (1998), social support networks may be left behind, a factor associated with homesickness in adults. For some there are cultural and linguistic differences to overcome. This is especially true of the present study, as nearly all of students in the present sample are from cities or villages other than Lahore. In addition to that there is an interruption of routines and habits together with a likely change in perceived role and sense of self. Rogers and Tennison (2009) propose that stress related to adjustment also contributes to emotional symptoms among college students. Common symptoms include depression, anxiety, and inability to cope (Grace, 1997). Poor mental health is also more common among students with relationship stressors and low social support. Moreover, there is also a connection between stress and poor health outcomes or disease (Damush, et al. 1997; Selye, 1976).

An interesting finding in nearly all of these studies is that female students, when living in dorms or hostels, face more problems than male students. For example, Wannebo and Wichstrom (2010), who investigated whether high school students living in lodgings were at an increased risk of internalizing problems, report that several studies of homesickness among university students show that females experience more homesickness and depression than males (Archer, et al. 1998; Stroebe, et al. 2002).

\section{Social support and Constructive Routines}

Social support is indeed very important in determining an individual's psychological wellbeing. In fact, Gerdes and Mallinckrodt (1994) found that social and emotional adjustment difficulties among first-year college students were actually better predictors of attrition than were academic difficulties. According to Wannebo and Wichstrom (2010), social support has a positive correlation with psychological disorders/mental health, and to act as a protective variable, moderating the relationship between life events and disorder (Compas, et al. 1986; Herman-Stahl \& Petersen, 1999). Living in a family and being with friends usually implies being involved in a variety of daily activities, such as socializing in the family, doing family chores, or leisure activities with friends. Such activities are found to be negatively associated with poor mental health in general and 
depression in particular (Burwell \& Shirk, 2006; Lewinsohn, et al. 1997; Lewinsohn, et al. 1998).

\section{Contributors to Satisfaction}

Various student residential aspects have been categorized with respect to satisfaction. Generally, these attributes have been categorized in the literature as social/psychological, management/organizational and physical attributes. Social attributes include privacy, neighbours, security and safety, social densities, freedom of choice, social relations and personalization (Francescato, et al. 1979; Spencer \& Barneji, 1985). The management attributes usually examined are rules and regulations, maintenance, management staff and policies, participation and rents (Paris \& Kangari, 2006). Physical attributes have been examined much less in the literature. They usually include the lack or presence of certain facilities, spatial density, location and size of the bedroom (Galster, 1987; Kahana, et al. 2003; Peck \& Stewart, 1985; Turkoglu, 1997).

Interestingly, Amole's study (2008) shows that as economic status increased, satisfaction decreased. According to Amole (2008), increasing economic status implies increasing aspirations and a decrease in satisfaction if the housing situation remains the same. Furthermore, the study showed that the longer the students stayed the more satisfied they became. This is probably because with time, they adapted to the living conditions of their housing and also devised coping strategies which improved their level of satisfaction. In addition to length of stay, age was also a predictor of satisfaction.

\section{Rationale for the Research}

There have been very few studies in Pakistan that gauge the impact of the college or hostel environment on the students' lives. In fact, there have been no studies in Pakistan that compare the environment of two hostels and their subsequent effects on students. This study aims to bring this overdue issue to light and to make a contribution in this area. This study also aims to highlight the importance of not simply the physical, but also the psychological aspects, of the residential environment on the students' psychological wellbeing, life satisfaction and consequently, their academic and social lives. This topic is of utmost importance since education and hostel enrollment in Pakistan is increasing.

Students migrating from far away, underdeveloped cities and villages, apart from adjusting to more demanding studies and taking responsibilities, have to adjust to an entirely new environment, with people following different customs, traditions, sometimes even a different language. Even for students who do not migrate from another city, transitioning from a home-life to a hostel-life can be difficult. This is made even more difficult if the hostel environment is unfriendly, unsupportive, restrictive, with few or 
inadequate material comforts provided, such as unclean bathrooms and rooms, poor heating or cooling, unappetizing food and few or no sources for recreational interests. All of these factors have their own due impact on the students' academic and social lives, though they are downplayed by concerned authorities. The study aims to bring a change in these views and to highlight the importance of bringing positive changes to such environments.

Despite the number of studies that have been conducted regarding Psychological wellbeing and life satisfaction, few have been conducted on students, especially hostel students, with respect to the effects of the hostel environment. As Chow and Healey (2008) note in their study of students' place attachment and place identity, little attention has been given to the situation of students making the transition from home to university.

\section{Hypotheses}

The following hypotheses were made:

a. Psychological wellbeing of private hostel students would be significantly higher than the government hostel students.

b. Life satisfaction of private hostel students would be significantly higher than the government hostel students.

c. Private Hostel environment would be significantly more satisfactory than the government hostel environment.

\section{Method \\ Participants}

For the purpose of current study, 95 participants (all women) who met the following criteria were recruited. The participants consisted of 50 students from a government hostel and 45 students from a private hostel in Lahore $(n=95)$. The age range of the participants was 17-27 years. Most of the participants were from outside cities or villages

\section{Measures}

\section{Demographic Information Sheet:}

The questions asked in the demographic sheet were related to age, family income, and native city. It asked information about parents, number of family members, birth order and relationship with family members, the duration of stay in the hostel, etc. 


\section{The Hostel Environment Rating Scale}

To rate the students' satisfaction with the environment, an indigenously developed scale was used for the study, The Hostel Environment Rating Scale (Shaukat \& Muazzam, 2010). The scale consists of 24 items, each rated on a 5 point, Likert-type scale, ranging from good to unsatisfactory. The environment, and therefore the scale, is categorized in two parts:

i. The physical environment (which consists of items related to hygiene levels, level of noise, crowding, quality of food, access to T.V. or library, etc.) and

ii. The emotional environment (which includes items such as relationship with roommates, with the warden, level of various restrictions, promotion of extracurricular activities, etc.).

The reliability coefficient for the scale was 0.88 .

\section{The Affect Balance Scale}

The Affect Balance Scale (Bradburn, 1965) was used to measure psychological wellbeing in college students. It is a 10-item rating scale containing five statements reflecting positive feelings and five statements reflecting negative feelings, which is administered to determine overall psychological well-being at a given point in time. The questions are presented in a yes or no format. Scores range from 0 to 5. The Affect Balance Scale score is computed by subtracting Negative Affect Scale scores from Positive Affect Scale scores and adding a constant of 5 to avoid negative scores. Scores range from 0 (lowest affect balance) to 10 (highest affect balance). Internal consistency results from several samples ranged from 0.55 to 0.73 for Positive Affect Scale (PAS) and from 0.61 to 0.73 for the Negative Affect Scale (NAS).

\section{The Satisfaction with Life Scale (SWLS)}

The Satisfaction with Life Scale (SWLS) is a measure of life satisfaction (Diener, Emmons, Larsen \& Griffin, 1985) consisting of five items. Scores are given from 1-7, ranging from strongly agree to strongly disagree. Diener et al. (1985) reported a coefficient alpha of 0.87 for the scale and a 2 month test retest reliability coefficient of 0.82 .

\section{Procedure}

After gaining permission from the warden of the hostel, the participants were approached individually or in the form of groups and briefed on how to fill the questionnaires. All the participants received same instructions. Descriptive statistics, means and standard 
deviations, and estimates of the internal consistency reliability of the instruments were obtained, after which correlational analyses; multiple regression analysis was used to identify the relative contribution of independent variables on effect variables.

\section{Results}

\section{Demographic Characteristics of Participants}

The sample consists of 86 participants. Table 1 shows the sample descriptive. 50 students were from a government hostel and 45 students from a private hostel in Lahore $(n=95)$. The mean age of the participants was 21.08.

Table: 1

Descriptive Statistics and Internal Consistencies for Study Scales (N=86)

\begin{tabular}{|l|c|c|c|c|}
\hline Scale & No. of items & M & SD & $\boldsymbol{\alpha}$ \\
\hline HERS & 24 & 75.09 & 18.33 & 0.88 \\
\hline ABS & 10 & 5.15 & 1.71 & 0.51 \\
\hline SWLS & 5 & 23.25 & 5.65 & 0.57 \\
\hline
\end{tabular}

*Note HERS $=$ Hostel Environment Rating Scale, ABS= Affect Balance Scale, SWLS= Satisfaction with Life Scale

\section{Independent Samples T-Test}

Independent samples t-test were generated to compare various demographic factors between the two groups. The results are given below.

Table: 2

Independent Samples T-Test Comparing Demographic Factors between the Two Groups $(\mathbf{N}=86)$

\begin{tabular}{|c|c|c|c|c|c|}
\hline Variable & Group & M & SD & t & p< \\
\hline Do you exercise? & $\begin{array}{c}\text { government } \\
\text { hostel }\end{array}$ & 1.41 & .54 & & \\
\cline { 2 - 5 } & private hostel & 1.95 & .79 & $3.57^{*}$ & .01 \\
\hline $\begin{array}{c}\text { Do you engage in } \\
\text { your favourite } \\
\text { pastime during your } \\
\text { stay in hostel? }\end{array}$ & $\begin{array}{c}\text { government } \\
\text { hostel }\end{array}$ & 1.80 & .75 & $3.94^{*}$ & .01 \\
\cline { 2 - 4 } & private hostel & 2.43 & .74 & & \\
\hline $\begin{array}{c}\text { Any physical health } \\
\text { problems }\end{array}$ & $\begin{array}{c}\text { government } \\
\text { hostel }\end{array}$ & 1.76 & .43 & & \\
\cline { 2 - 4 } & private hostel & 1.86 & .43 & 1.14 & .258 \\
\hline
\end{tabular}




\begin{tabular}{|c|c|c|c|c|c|}
\hline \multirow[t]{2}{*}{$\begin{array}{l}\text { Any mental health } \\
\text { problems }\end{array}$} & $\begin{array}{c}\text { government } \\
\text { hostel }\end{array}$ & 1.91 & .28 & \multirow[t]{2}{*}{2.66} & \multirow[t]{2}{*}{.791} \\
\hline & private hostel & 1.93 & .26 & & \\
\hline \multirow[t]{2}{*}{ Level of restrictions } & $\begin{array}{c}\text { government } \\
\text { hostel }\end{array}$ & 2.15 & 1.43 & \multirow[b]{2}{*}{$4.44 *$} & \multirow[b]{2}{*}{.01} \\
\hline & private hostel & 3.43 & 1.25 & & \\
\hline \multirow[t]{2}{*}{$\begin{array}{l}\text { Restrictions about } \\
\text { having parties }\end{array}$} & $\begin{array}{c}\text { government } \\
\text { hostel }\end{array}$ & 2.02 & 1.34 & \multirow[b]{2}{*}{$4.23 *$} & \multirow[b]{2}{*}{.01} \\
\hline & private hostel & 3.21 & 1.29 & & \\
\hline \multirow[t]{2}{*}{ Permission to go out } & $\begin{array}{c}\text { government } \\
\text { hostel }\end{array}$ & 1.83 & 1.43 & \multirow[b]{2}{*}{$7.35^{*}$} & \multirow[b]{2}{*}{.01} \\
\hline & private hostel & 3.95 & 1.17 & & \\
\hline \multirow[t]{2}{*}{$\begin{array}{c}\text { Permission to go } \\
\text { home when possible }\end{array}$} & $\begin{array}{c}\text { government } \\
\text { hostel }\end{array}$ & 2.28 & 1.54 & \multirow[b]{2}{*}{$8.24 *$} & \multirow[b]{2}{*}{.01} \\
\hline & private hostel & 4.45 & .77 & & \\
\hline \multirow[t]{2}{*}{$\begin{array}{l}\text { Your opinion about } \\
\text { the warden }\end{array}$} & $\begin{array}{c}\text { government } \\
\text { hostel }\end{array}$ & 2.76 & 1.49 & \multirow[b]{2}{*}{$4.61 *$} & \multirow[b]{2}{*}{.01} \\
\hline & private hostel & 4.09 & 1.18 & & \\
\hline $\mathrm{df}=86, * * * \mathrm{p}<.01$ & & & & & \\
\hline
\end{tabular}

It was found that many factors seemed to have a significant relationship with the two groups and their respective wellbeing, satisfaction with life and satisfaction with environment. The first is exercise; the private group had higher ratings of exercise $(M=1.95, S E=.12)$ as compared to the government group $(M=1.41, S E=.079)$. The differences were significant $t(86)=3.79, p<0.01$. Engaging in some extracurricular activities also yielded significant differences, i.e. the score of the private group was $(M=2.43, S E=.11)$ as compared to the government group scores $(M=1.80, S E=.11)$. Factors that also had a significant relationship with the two groups were opinion about the warden, permission to go home when possible and level of restrictions, as shown in the table above. The differences was again significant $t(86)=6.77, p<0.01$. However, other factors did not have a significant relationship, as shown in the table below. Level of income and duration of stay in the hostels also did not have a significant relationship.

\section{Psychological Wellbeing, Life Satisfaction and Demographic Variables}

Analyses were performed to find out the relationship between psychological wellbeing, life satisfaction, demographic and environmental variables. 
Table: 3

Independent Samples t-Test Comparing Private and Government Hostel Groups across Total Scores of Affect Balance Scale

\begin{tabular}{|c|c|c|c|c|c|}
\hline Variables & Group & M & SD & $\mathbf{t}$ & $\mathbf{p}<$ \\
\hline ABS & Private & 6.59 & 1.53 & $4.48^{*}$ & 0.05 \\
& Government & 4.80 & 2.19 & & \\
\hline
\end{tabular}

$d f=86, p<0.05$

Analyses revealed there is a significant difference in the levels of psychological wellbeing between the two groups. The private hostel group obtained higher scores on the ABS scale $(M=6.59, S E=.23)$ than the government hostel group $(M=4.80, S E=.32)$. The differences were significant $t(86)=4.41, p<.05$.

\section{Table 4}

Independent Samples t-Test Comparing Private and Government Hostel Groups across Total of Satisfaction with Life Scale

\begin{tabular}{|c|c|c|c|c|c|}
\hline Variables & Group & M & SD & t & p $<$ \\
\hline SWLS & Private & 22.61 & 4.89 & 1.00 & \\
& Government & 23.82 & 6.27 & & 0.13 \\
\hline
\end{tabular}

$d f=86, p>0.05$

For the Satisfaction with Life scale, the differences were not significant.

Table 5

Independent Samples t-Test Comparing Private and Government Hostel Groups across Total of Satisfaction with Physical and Psychological Environment Scale (SPPES)

\begin{tabular}{|c|c|c|c|c|c|}
\hline Variables & Group & M & SD & t & p \\
\hline SPESS & Private & 86.31 & 15.03 & $6.74 *$ & 0.01 \\
& Government & 64.85 & 14.80 & & \\
\hline$d f=86, p<0.01$.
\end{tabular}

The most highly significant results were achieved with the Satisfaction with Physical and Psychological Environment Scale (SPPES). The score was much more significant, i.e. the private group obtained much higher scores $(M=86.31, S E=2.3)$ as compared to the government group ( $\mathrm{M}=64.85, \mathrm{SE}=2.1)$. The differences were significant $t(86)=6.74$, $p<0.01$. 


\section{Discussion}

The present findings reveal that there is indeed a high level of difference between the environments of the private hostel and the government hostels, thus proving Hypotheses 1 and 3. This finding is highly significant in Pakistan where little importance is given to the environment of residents, especially the residential environment of students. In the present research, the scores in the scales used show that although the physical environment of the government hostel is considerably less satisfactory than that of the private hostel, the most significant results are seen in the ratings of the psychological environment of the hostel, which are markedly lower for the government hostel than the private hostel, specifically in the following areas: level of restrictions, restrictions about having parties, permission to go out, permission to go home when possible and opinion about the warden. Results also confirm that the levels of psychological wellbeing for the private hostel student are significantly higher than the government hostel students. A positive relation can be drawn between the satisfaction with environment and the psychological wellbeing of hostel students, i.e. the more the students are satisfied with their environment, the greater their psychological wellbeing.

Some of the findings of the present study are in line with previous studies. For example, if the individual fails to adapt and negative feelings within the new environment persist, it has been shown to be associated with high levels of loneliness, depression, increased physical health problems and allied difficulties (Fisher, 1988). This has been proven by the results of the present study, which show that government hostel students, who have lower scores on the Hostel Environment Rating Scale have subsequently lower scores on the Affect Balance Scale.

Another reason for lower scores of psychological wellbeing of the government hostel group, besides dissatisfaction with the environment, is poor social support. The present study shows a significant difference between the t-test means of the private and the government group in items such as: the permission to go out, permission to go home when possible and permission for having parties. According to Wannebo and Wichstrom (2010), social support is found to be directly related to mental health, and to act as a buffer in stressful times (Compas, Slavin, Wagner, \& Vannatta, 1986; Herman-Stahl \& Petersen, 1999). Denying the students permission to go home when possible, permission to going out or having parties is akin to denying them social support. Also, some investigations report that wellbeing is more strongly affected by negative social interactions than by positive interactions (Rook, 1984; Abbey, Abramis \& Caplans, 1985). According to Lincoln (2000), negative interactions may include discouraging the expression of feelings, making critical remarks, invading another's privacy or failing to provide promised help, etc. These are especially significant with respect to the ratings about the opinion about the Warden of the college. A warden is akin to a parent-figure, 
therefore if negative interactions result, these may lead to high stress and low wellbeing. This has been demonstrated by another study in South Africa, which showed that students who were comfortable discussing their personal problems with the warden were significantly more satisfied than students who did not (Botha, Snowball, de Klerk \& Radloff, 2013).

Hypothesis 2, that life satisfaction would be greater for private students was not proven. There can be a number of reasons for this. In contrast to the Affect Balance Scale, the statements in the Satisfaction with Life Scale are very straightforward and reveal the basic purpose of the test (i.e. satisfaction with life); also, by having a small number of items, it cannot counteract the effects of lying. Pakistani girls may feel guilty or ungrateful if they respond negatively to "I am satisfied with my life", "my life is close to ideal", "the conditions of my life are excellent", etc.

A limitation of this study is that the scales were not translated in Urdu. Although the sample comprised of educated, college-going women, who all had an understanding of English, the language may still have acted as a barrier. Another limitation of this study is the small sample size. The study compares the differences between only one private hostel and one government hostel; therefore the findings cannot be generalized to other hostels. Despite the limitations, the study establishes a relationship of the students' wellbeing with their physical and psychological hostel environment, and compares the environment of two different types of hostels, which has not been researched before. The study makes a contribution especially in Pakistan, where literature in this regard is lacking.

\section{Conclusions}

The study is unique in the respect that no study has compared the environment of two hostels and then tried to evaluate its effects on the students' wellbeing and life satisfaction. In summary, findings from this study underscore the importance of the student residential environment on the students' functioning. A basic understanding of the prevalence and correlates of mental disorders among college students is emerging, but less is known about approaches that go beyond the clinical level to improve mental health in this population. Although it is intuitive that contextual factors such as extra curricular activities, residential settings, and the supportiveness of academic personnel would affect student mental health, researchers have yet to examine these relationships rigorously, especially in Pakistan. In addition, the evidence on interventions, programs, and policies is especially lacking. 


\section{References}

Abbey, A., Abramis, D. J., \& Caplan, R. D. (1985). Effects of Different Sources of Social Support and Social Conflict on Emotional Well-being, Basic and Applied Social Psychology, vol. 6, pp. 111-129.

Adams, G., King, L., \& King, D. (1996). Relationships of job and Family Involvement, Family Social Support, and Work-Family Conflict with Job and Life Satisfaction, Journal of Applied Psychology, vol. 81, pp. 411-420.

Amole, D. (2008). Residential Satisfaction in Students' Housing, Journal of Environmental Psychology, vol. 29, pp. 76-85.

Archer, J., Ireland, J., Amos, S., Broad, H., \& Currid, L. (1998). Derivation of a Home Sickness scale. British Journal of Psychology, vol. 89, 205-221.

Bell, J. \& Bromnick, R. (1998). Young People in Transition: The Relationship between Homesickness and Self-Disclosure, Journal of Adolescence, vol. 21, pp. 745-748.

Botha, F., Snowball, J., de Klerk, V. \& Radloff, S. (2013). Determinants of Student Satisfaction with Campus Residence Life at a South African University (Working Paper No. 338), Retrieved from Economic Research Southern Africa (ERSA) website: http://www.academia.edu/2906909

Bradburn, N. M.(1969). The Structure of Psychological Well-Being. Chicago: Aldine.

Burwell, R. A., \& Shirk, S. R. (2006). Self Processes in Adolescent Depression: The Role of Self-Worth Contingencies, Journal of Research on Adolescence, vol. 16, pp. 479-490.

Butt, B. Z. (2010). A Study Examining the Students' Satisfaction in Higher Education. Procedia Social and Behavioral Sciences, vol. 2, pp. 5446-5450.

Butt, Z. H. \& Rehman, K. (2010). A Study Examining the Students Satisfaction in Higher Examination, Procedia Science and Behavioural Sciences, vol. 2, pp. 5446-5450.

Chow, K. and Healey, M. (2008). Place Attachment and Place Identity: First Year Undergraduates Making the Transition from Home to University, Journal of Environmental Psychology, vol. 28, pp. 362-372. 
Compas, B. E., Slavin, L. A., Wagner, B. M., \& Vannatta, K. (1986). Relationship of Life Events and Social Support with Psychological Dysfunction among Adolescents, Journal of Youth and Adolescence, vol. 15, pp. 221.

Damush, T. M., Hays, R. D., \& DiMatteo, M. R. (1997). Stressful Life Events and Health-Related Quality of Life in College Students, Journal of College Student Development, vol. 38 (2), pp. 181-190.

Diener, E. (2006). Guidelines for National Indicators of Subjective Well-being and Illbeing, Applied Research in Quality of Life, vol. 1, pp. 151-157.

Diener, E. (1984). Intensity and Frequency: Dimensions underlying Positive and Negative Affect, Journal of Personality and Social Psychology.

Fisher, S., Fraser, N., \& Murray, K. (1986). Homesickness, Health and Efficiency in First Year Students, Journal of Environmental Psychology, vol. 5, pp. 181-195.

Fisher, S., \& Hood, B. (1988). Vulnerability Factors in the Transition to University: SelfReported Mobility History and Sex Differences as Factors in Psychological Disturbance, British Journal of Psychology, vol. 79, p. 309.

Francescato, G., Weidemann, S., Anderson, J., \& Chenoweth, R. (1979). Residents' Satisfaction in HUD-assisted Housing: Design and Management Factors, Washington DC: Department of Housing and Urban Development.

Galster, G.C. (1987). Identifying the Correlates of Dwelling Satisfaction: An Empirical Critique, Environment and behaviour, vol. 19 (5), pp. 539-568.

Gerdes, H., \& Mallinckrodt, B. (1994). Emotional, Social, and Academic Adjustment of Cnts: A Longitudinal Study of Retention, Journal of Counseling and Development, vol. 72, pp. 281-288.

Grace, T. (1997). Health Problems of College Students, Journal of American College Health, vol. 45 (6), pp. 243-251.

Halamandaris, K. F. \& Power, K.G. (1999). Individual Differences, Social Support and Coping with the Examination Stress: A Study of the Psychosocial and Academic Adjustment of First Year Home Students, Personality and Individual Differences vol. 26, pp. 665-685. 
Herman-Stahl, M., \& Peterson, A.C. (1999). Depressive Symptoms during Adolescence: Direct and Stress-Buffering Effects of Coping, Control Beliefs, and Family Relationships, Journal of Applied Developmental Psychology, vol. 20, pp. 45-62.

Kahana, E., Lovegreen, L., B., K. \& Kahana, M. (2003). Person, Environment, and Person-Environment as an Infuences on Residential Satisfaction of Elders, Environment and behaviour, vol. 35, pp. 434-453.

Lent, R.W., Ceu Taveira, M., Sheu, H. \& Singley, D. (2009). Social Cognitive Predictors of Academic Adjustment and Life Satisfaction in Portuguese College Students: A Longitudinal Analysis, Journal of Vocational Behaviour, vol. 74, pp. 190-198.

Lewinsohn, P. M., Gotlib, I. H., \& Seeley, J. R. (1997). Depression-Related Psychosocial Variables: Are they Specific to Depression in Adolescents? Journal of Abnormal Psychology, vol. 106, pp. 365-375.

Lewinsohn, P. M., Rohde, P., \& Seeley, J. R. (1998). Major Depressive Disorder in Older Adolescents: Prevalence, Risk Factors, and Clinical Implications. Clinical Psychology Review, vol. 18, pp. 765-794.

Lincoln, K. D. (2000). Social Support, Negative Social Interactions, and Psychological Well-Being, Social Service Review, vol. 74 (2), pp. 231-252.

Muslim, M.H., Abdul-Karim, H., \& Abdullah, I.C. (2012). Satisfaction of Students' Living Environment between On-Campus and Off-Campus Settings: A Conceptual Overview, Procedia Social and Behavioural Sciences, vol. 68, pp. 601-614.

Paris, E. \& Kangari, R. (2006). Multifamily Affordable Housing: Residential Satisfaction. Journal of Performance of Constructed Facilities, vol. 19 (2), pp. 138-45.

Peck, C. \& Stewart, K.K. (1985). Satisfaction with Housing and the Quality of Life, Family and Consumer Sciences Research Journal, pp. 13363-372.

Rogers, L. S. \& Tennison, L. R. (2009). A Preliminary Assessment of Adjustment Disorder among First-Year College Students, Archives of Psychaitric Nursing, vol. 23, pp. 220-230.

Rook, K. (1984). The Negative Side of Social Interaction, Journal of Personality and Social Psychology, vol. 46, pp. 1097-1118.

Ryff, C. D. (1989). Happiness is Everything, or is it? Explorations on the Meanings of Psychological Well-being, Journal of Personality and Social Psychology, vol. 57, pp. 1069-1081. 
Selye, H. (1976b). The Stress of Life (Rev. ed.). New York, NY: McGraw-Hill.

Shanfa,Y. (2008). Psychosocial Work Environment and Well-being: a Cross-sectional Study at a Thermal power Plant in China, Journal of Occupational Health, vol. 50, pp. $155-162$.

Shaukat, F. \& Muazzam, A. (2010). Comparison of Psychological Well-being and Life Satisfaction between Private and Government Female Hostel Students, (Unpublished bachelor's thesis), Lahore College for Women University, Lahore.

Shaver, P., Furman, W., \& Buhrmester, D. (1986). Transition to College: Network Changes, Social Skills, and Loneliness, In S. Duck, \& D. Perlman (Eds.),

Understanding personal relationships: An interdisciplinary approach (pp. 193-219). Beverly Hills: Sage.

Spencer, C., \& Barneji, N. (1985). Strategies for Sharing Student Accommodation: A Comparison of Male and Female Student Responses to Single and Shared Rooms, Architecture and Behaviour vol. 2, pp. 123-135.

Stroebe, M., van Vliet, T., Hewstone, M., \& Willis, H. (2002). Homesickness among Students in Two Cultures: Antecedents and Consequences, British Journal of Psychology, vol. 93, p. 147.

Turkoglu, H. D. (1997). Residents' Satisfaction of Housing Environments: The Case of Istanbul, Turkey, Landscape and Urban Planning, vol. 39, pp. 55-67.

Wannebo, W., \& Wichstrom, L. (2010). Are High School Students Living in Lodgings at a Increased Risk for Internalizing Problems? Journal of Adolescence, vol. 33 (3), pp. 430-47.

Fatima Shaukat is BS Research Scholar in the Department of Applied Psychology, Lahore College for Women University.

Dr. Amina Muazzam Butt is Assistant Professor in the Department of Applied Psychology, Faculty of Social Sciences Lahore College for Women University. 